FOLIA

HORTICULTURAE

Ann. 20/1, 2008, 3-14

DOI: $10.2478 /$ fhort-2013-0101

\title{
Growth, yielding and susceptibility to fire blight of cider apples in the climatic conditions of Central Poland
}

\author{
Alojzy Czynczyk ${ }^{1}$, Danuta Chlebowska ${ }^{1}$, Tim Epps ${ }^{2}$ \\ ${ }^{1}$ Research Institute of Pomology and Floriculture \\ Pomologiczna 18, 96-100 Skierniewice, Poland \\ e-mail: aczynczy@insad.pl \\ ${ }^{2}$ HP Bulmer Limited, The Cider Mills, Plough Lane \\ Hereford HR4 OLE, England \\ e-mail: tim.epps@s-n.com
}

Key words: cider apples, rootstock, growth, yield, fire blight, winter hardiness

\begin{abstract}
The possibility of growing 8 cider apple cultivars on M.26, P 14 and Antonovka seedlings in the climatic conditions of Central Poland was studied over a period of 7 years $(1996-2003)$. The results obtained showed that cultivars of cider apples are more susceptible to fire blight than standard cultivars 'James Grieve', 'Wealthy' and 'Common Antonovka'. After seven years of growth, the most vigorously growing cultivars on the three rootstocks were 'Ellis Bitter' and 'Major', and on Antonovka seedlings also 'Yarlington Mill' and 'Harry Masters' Jersey'. The weakest growth was shown by 'Ashton Bitter' and 'Michelin' on all three rootstocks. Trees of cider cultivars 'Dabinett', 'Michelin', 'Ashton Bitter' and 'Chisel Jersey' were similar in size to standard cultivar 'James Grieve'. After
\end{abstract}


the seven-year period, the highest cumulative yields were obtained from 'Dabinett', 'Chisel Jersey' and 'Yarlington Mill' grown on all three rootstocks. A high cumulative yield was also obtained from 'Major' grafted on M.26 and P 14 and 'Michelin on P 14 and Antonovka seedlings. 'Dabinett', 'Major' and 'Chisel Jersey' were high productive cultivars and can be recommended for growing on $\mathrm{P}$ 14 and Antonovka seedlings in commercial orchards in Poland.

\section{INTRODUCTION}

Cider varieties of apple are completely unknown in Poland. There is no basic information on the possibility of growing such varieties in the fairly changeable climate of Poland. In contrast, cultivars that produce such apples have been quite commonly cultivated in England, France, Spain, Germany and Switzerland (Williams 1992, Fuertes et al. 1996, Höhn and Leumann 2004).

Cider apples are used for the production of cider, a kind of dry wine with a slightly tart taste derived from a high concentration of tannin - a natural tanning agent. Tannin is commonly used for medicinal purposes as a remedy for diarrhoea, as well as in dyeing and tanning industries. As a result of the chemical analyses carried out on cider apple varieties it was found that the tannin content in those apples was from twice to four times as high as in the apples of standard cultivars such as 'James Grieve', 'Wealthy' or 'Common Antonovka' (Czynczyk 2002, 2003). The fairly widespread cultivation of cider apples in West European countries is an encouragement for carrying out trials on the possibility of growing these cultivars in the Polish climate. According to Williams (1992), trees producing cider apples require a mild climate without too low temperatures. The increasing warming of climate in Poland should thus favour successful growing of cider apples in Poland.

Survival tests recommended by Hołubowicz (1978) conducted during three consecutive winters $(1999 / 2000,2000 / 2001$ and 2001/2002) involving the freezing of one-year-old shoots at temperatures between $-20^{\circ} \mathrm{C}$ and $-35^{\circ} \mathrm{C}$ three times each winter showed that winter hardiness of cider apple cultivars was similar to that of the standard cultivars 'James Grieve' and 'Wealthy'. However, the shoots of all tested cider cultivars were found to be more sensitive to lower temperatures than those of standard cultivar 'Common Antonovka' (Czynczyk 2001, 2002, 2003).

The aim of the experimental work, commissioned by HP Bulmer Limited, The Cider Mills, Hereford, England, was to determine the possibility of cultivating cider apples in fairly changeable climate of Poland by considering the health and frost resistance of trees, particularly their growth, yielding and productivity in comparison with standard cultivars. 


\section{MATERIAL AND METHODS}

To establish the experiment, one-year-old trees of eight cider cultivars (Table 1) grafted on three rootstocks: M.26, P 14 and Antonovka seedlings, were used. The control function was fulfilled by standard cultivars 'James Grieve', 'Wealthy' and 'Common Antonovka' grafted on Antonovka seedlings. All trees were budded at the height of 5 to $9 \mathrm{~cm}$ above ground level. The experimental orchard was set up in the autumn of 1996 on a podsolic soil overlaying heavy clay in the Experimental Orchard at Dąbrowice, near Skierniewice in Central Poland, using random block methods with three replications and four trees per plot. All trees grafted on M.26 and P 14 were planted at the same distance of $4.0 \times 2.5 \mathrm{~m}$, while the trees grafted on Antonovka seedlings were planted at a larger distance of $4.0 \times 3.0 \mathrm{~m}$. All trees were trained in the form of a slender spindle. Fertilization, soil cultivation and orchard protection procedures were applied according to the recommendations for commercial orchards.

During the growth period, tree health status and winter hardiness were evaluated, and tree trunk thickness measurements and fruit yields were recorded annually. In $2002-2003$ the weight of the fruits was assessed. Additionally, appearance symptomatic of the severity of fire blight, which occurred in 2002 was determined according to the following scale: $1-(0-20 \%$ infected shoots, very low $)$, 2 - (21-40\%, low), 3 - (41-60\%, moderate), 4 - (61-80\%, high), 5 - (81-100\%, very high). Tree size, represented by the trunk's cross-sectional area at a level of about $30 \mathrm{~cm}$ above the ground, as well as fruit yield and weight were analyzed statistically using the variance analysis method for different number of replications. To evaluate the significance of the differences between the means, Duncan's test with the $5 \%$ significance level was used.

\section{RESULTS AND DISCUSSION}

\section{Tree health and winter hardiness}

In the seven-year period of tree growth $(1996$ - 2003) there were no winters severe enough to cause damage to the above-ground parts of cider apple trees of tested cultivars. The minimum temperatures recorded during the consecutive winters did not exceed $-22^{\circ} \mathrm{C}$. However, in the winter of $2002 / 2003$, the temperature of $-25.4^{\circ} \mathrm{C}$ was recorded on $9^{\text {th }}$ January. These low temperatures did not cause any damage to one-year-old shoots of cider apples. Lowest temperatures most often occurred after longer periods of below-zero temperatures, which helped the trees to build up resistance. 


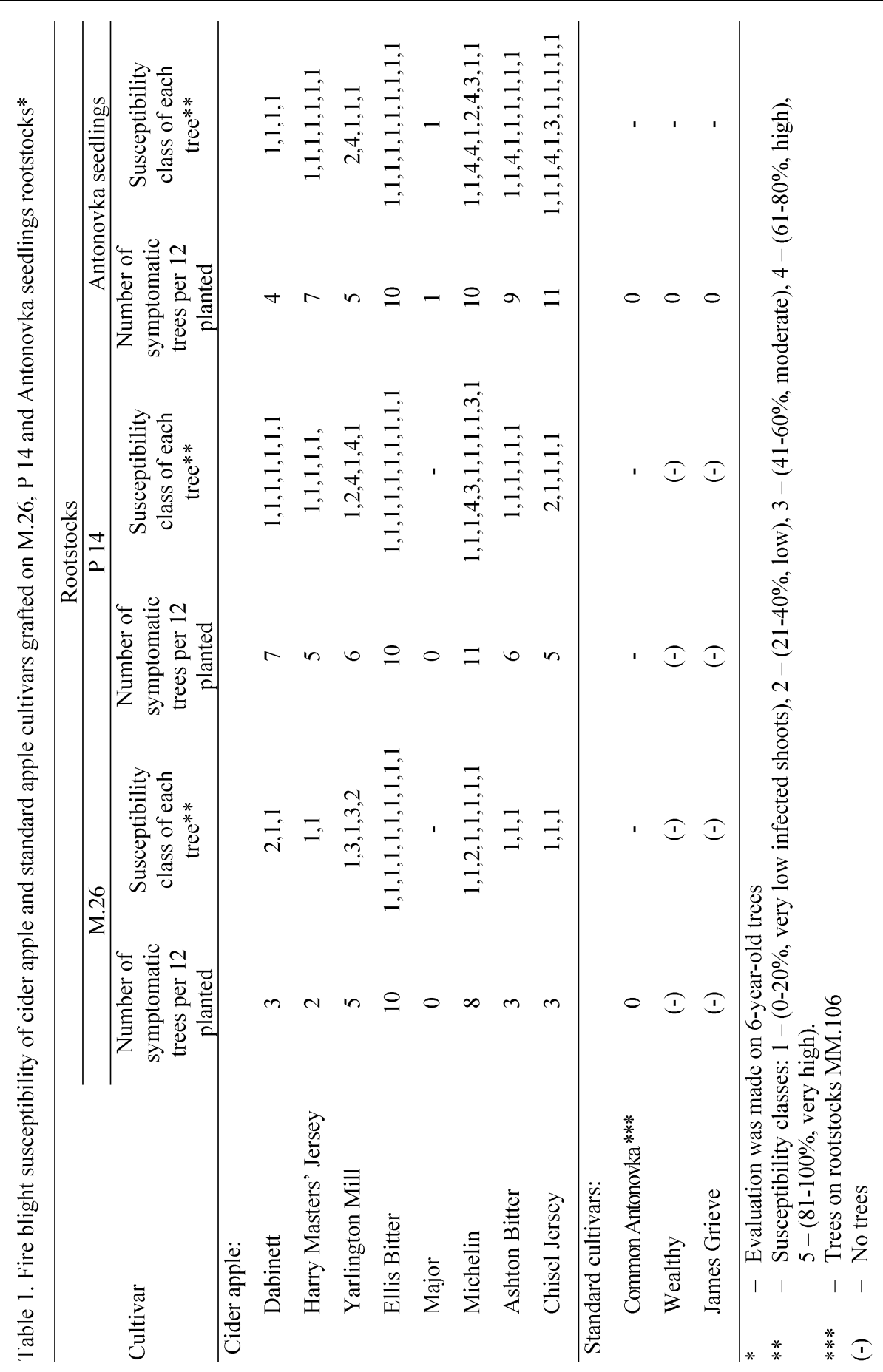


From the third year after planting, mild symptoms of perennial canker infection were observed each year on the stems of the following cultivars: 'Michelin', 'Chisel Jersey', 'Dabinett' and 'Ellis Bitter'. Mild symptoms of perennial canker were usually callused over during the summer.

In the sixth year after planting (2002), a quite serious fire blight (Ervinia amylovora) occurrence on young shoots and branches of almost all cider cultivars was observed. Highest number of infected shoots and branches was found on 'Michelin', 'Ellis Bitter', 'Ashton Bitter', 'Chisel Jersey' and 'Yarlington Mill'. Only a few symptomatic shoots were observed in the other cider apple cultivars, and one tree of 'Major' cultivar had a few infected shoots (Table 1). All of cider apple cultivars were more susceptible to fire blight than standard cultivars 'Common Antonovka', 'Wealthy' and 'James Grieve'. A higher number of shoots infected by Ervinia amylovora was noticed on vigorously growing trees of Antonovka seedlings and P 14, than on weaker growing trees on M.26. These results are in consistent with the results of Williams (1992) and Sobiczewski et al. (1997). During summer time, the removal of all new blighted shoots was carried out three times. Most of the trees affected by fire blight ( 8 trees of 'Michelin', 6 trees of 'Yarlington Mill', 3 trees of 'Chisel Jersey' and 1 tree of 'Ashton Bitter') were cut down in late winter of 2002/2003. A high number of infected trees of 'Michelin', 'Ellis Bitter', 'Chisel Jersey', 'Ashton Bitter' and 'Yarlington Mill', confirmed high susceptibility of these cultivars to fire blight, which is consistent with the results of Van der Zwet (1993, 1996). In 2003, an additional, very intensive programme of controlling the disease was applied by spraying trees with copper oxychloride twice before blooming, and 2-3 times during the blooming time with Hortocyna containing streptomycin of sulphate (Van der Zwet and Beer 1995, Sobiczewski et al. 1997). All shoots showing fresh symptoms of the disease were removed. This intensive programme of controlling fire blight was successful in preventing disease from recurring. In 2004, there was no incidence of new infections.

\section{Tree vigour}

The results of trunk thickness measurements in the seventh year after planting showed that the most vigorous trees on three rootstocks were 'Ellis Bitter' and 'Major', as well as 'Yarlington Mill' and 'Harry Masters' Jersey' on Antonovka seedlings (Tables 2, 3, 4). The weakest growth was shown by 'Ashton Bitter' and 'Michelin' on all three rootstocks. Small trees were also produced by standard cultivars 'Common Antonovka' and 'Wealthy' on Antonovka seedlings. These cultivars were significantly smaller than cider cultivars 'Yarlington Mill', 'Ellis Bitter', 'Harry Masters' Jersey' and 'Major'. The trees of cider cultivars 'Dabinett', 


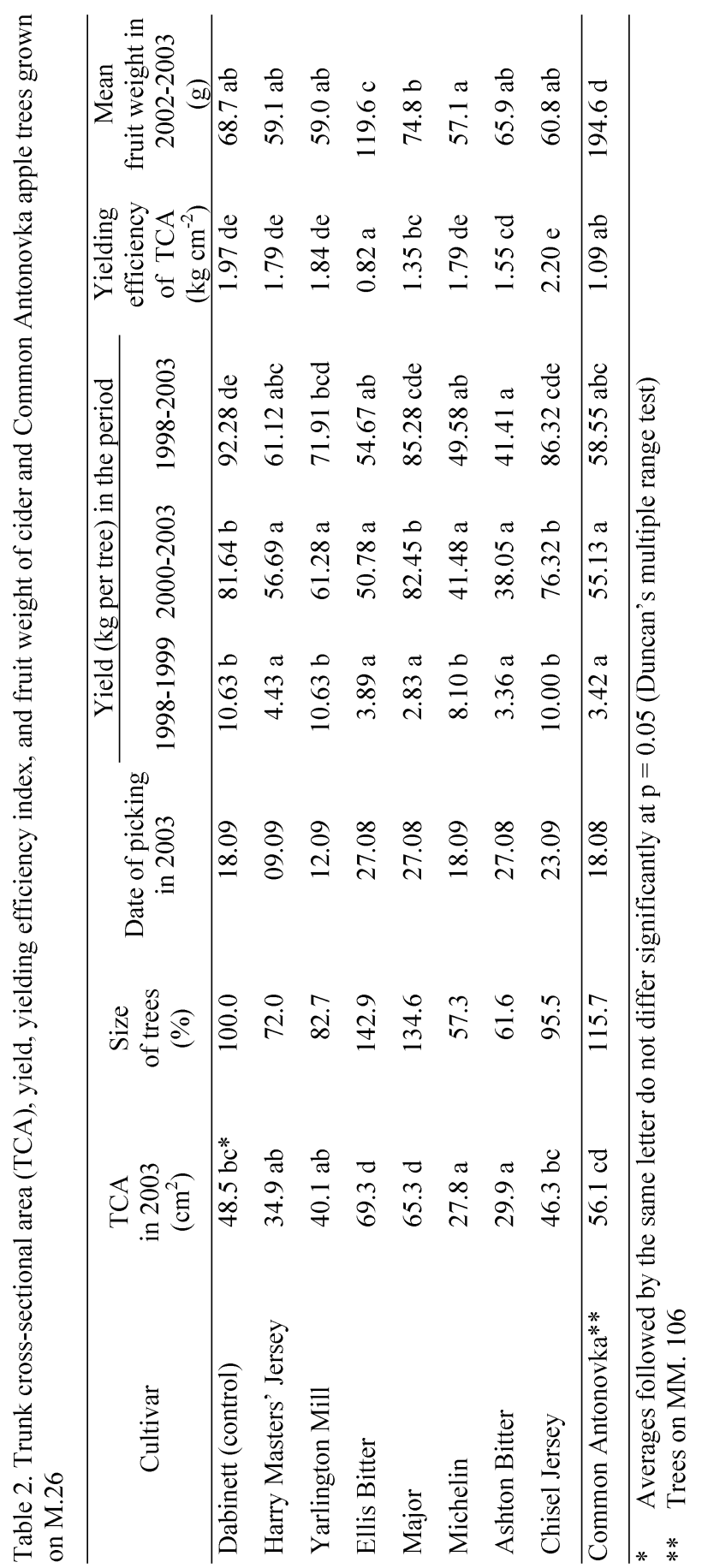




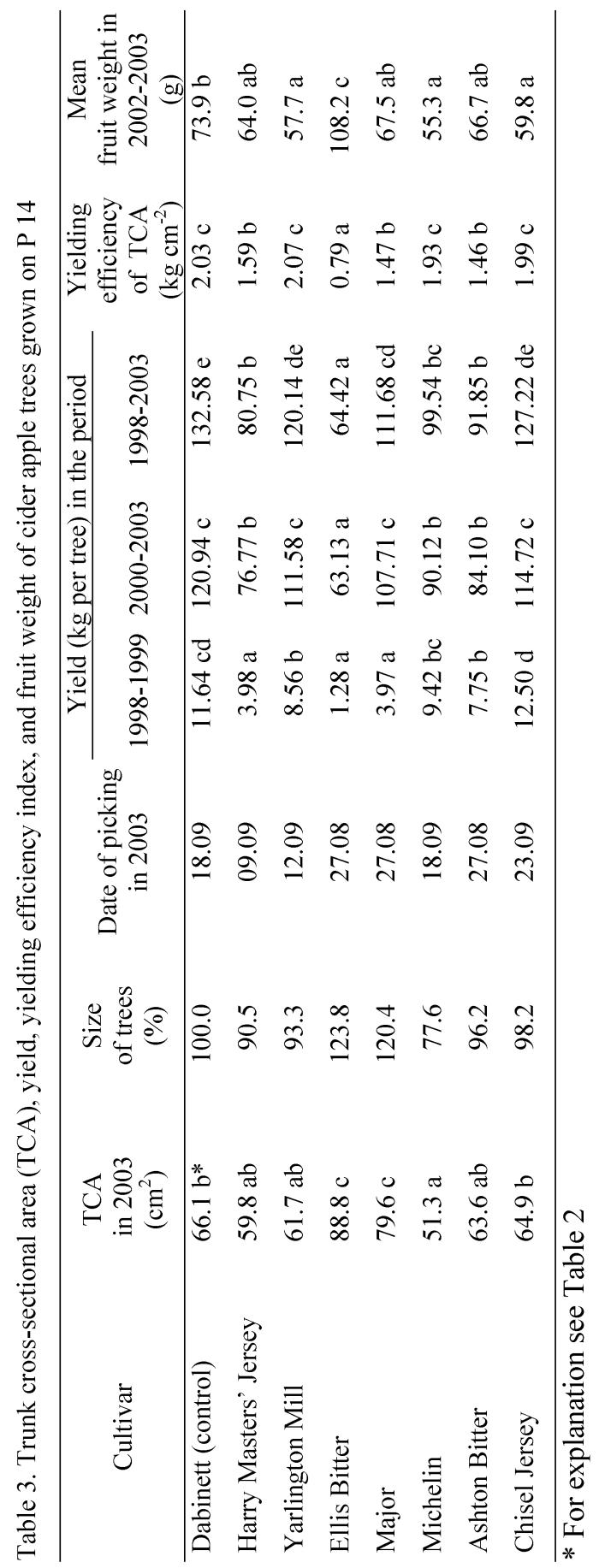


'Michelin', 'Ashton Bitter' and 'Chisel Jersey' were similar in size to those of standard cultivar 'James Grieve'. The results presented here in relation to the growth vigour of cider apple cultivars are comparable with the data published by Williams (1992).

\section{Flowering}

The blooming of cider apple trees usually began in the first 10 days of May, one or two days later than the standard cultivar 'James Grieve'. The period of blooming was usually prolonged until the $20^{\text {th }}$ of May, 2-4 days longer than the blooming period of standard cultivar 'James Grieve'. The earliest flowering cider cultivars were 'Major', 'Ashton Bitter' and the standard cultivar 'Wealthy'. The last to flower were cultivars 'Michelin', 'Harry Masters' Jersey' and 'Chisel Jersey'. The order of blooming dates agrees with the data published by Williams (1992) and Morgan and Richards (2002). The intensity of blooming in 2003 was high because yielding in 2002 was very low. Most of cider cultivars start alternate bearing very early.

\section{Picking dates}

In the year 2003, picking dates for standard cultivars were earlier by about one week compared with the average for the last 20 years. The first cider cultivars to be harvested ( $27^{\text {th }}$ August) were 'Ellis Bitter', 'Major', 'Ashton Bitter' and standard cultivars 'Common Antonovka' (18 ${ }^{\text {th }}$ August) and 'James Grieve' $\left(20^{\text {th }}\right.$ August $)$. The cultivars harvested last were 'Chisel Jersey' $\left(23^{\text {rd }}\right.$ September) and 'Dabinett' and 'Michelin' (18 ${ }^{\text {th }}$ September) (Tables 2, 3, 4). Hot weather in August and no rainfall in September did not hasten fruit ripening.

\section{Yielding}

All cider cultivars except for 'Ashton Bitter' grafted on M.26 and 'Common Antonovka' on MM.106 were found to have started bearing fruit in the second year after planting. The yields collected from cider cultivars were small and varied between 0.1 and $1.0 \mathrm{~kg}$. Among cider cultivars grafted on rootstock P 14 only 'Harry Masters' Jersey', 'Dabinett' and 'Michelin' bore a few fruits. In the second year after planting, cider cultivars grafted on Antonovka seedlings did no bear any fruits. All of three standard cultivars grafted on Antonovka seedlings produced some fruits in the second year after planting. The results obtained for Antonovka seedlings showed that cider cultivars start bearing fruit one year later than standard cultivars. In the next two years of fruiting (1998 and 1999), highest cumulative yields were obtained from 'Dabinett' and 'Chisel Jersey' grafted on all three 
rootstocks, and also from 'Yarlington Mill' on M.26. Much higher yields were produced by cider cultivars grafted on semi-dwarfing rootstocks P 14 and M.26 than on Antonovka seedlings. Smallest yields were obtained from 'Major' and 'Ellis Bitter' grown on all three rootstocks, and from 'Ashton Bitter' grown on Antonovka seedlings. Small yields were also obtained from all of three standard cultivars grafted on Antonovka seedlings. In the subsequent four years (2000 - 2003), highest cumulative yields were obtained from 'Dabinett', 'Major' and 'Chisel Jersey' grown on all three rootstocks. High yields were also obtained from 'Michelin' and 'Yarlington Mill' grafted on P 14 and Antonovka seedlings. A high yield was also picked from 'James Grieve' grafted on Antonovka seedlings. After seven years, highest cumulative yields were obtained from the following cultivars: 'Dabinett', 'Chisel Jersey', and 'Yarlington Mill' grown on all three rootstocks. High cumulative yields were also produced by 'Major' grafted on M.26 and P 14, and 'Michelin' on P 14 and Antonovka seedlings (Tables 2, 3, 4).

The highest total yields in $\mathrm{kg}$ per $1 \mathrm{~cm}^{2}$ of trunk cross-sectional area (TCA) were achieved by 'Chisel Jersey' and 'Dabinett' grafted on all three rootstocks. High yielding efficiency indexes were also recorded for 'Michelin' on P 14 and Antonovka seedlings, and 'Yarlington Mill' on P 14 and M.26 (Tables 2, 3, 4). The high productivity of these cultivars is comparable with the data presented by Williams (1992). The size of the fruit yield often corresponded to the size of the tree. The cultivars 'Dabinett', 'Major' and 'Chisel Jersey' were the most productive and can be recommended for growing on P 14 and Antonovka seedling rootstocks in commercial orchards in Poland. The mean fruit weight of most cider cultivars varied between 55 and $85 \mathrm{~g}$. Only the fruits of 'Ellis Bitter' weighed over $100 \mathrm{~g}$. The weights of apples of standard cultivars were much higher (Tables 2, 3, 4). The average crop produced by all eight cider cultivars on Antonovka seedlings in 2003 was only $30 \mathrm{~kg}$ per tree. This means that the estimated yield from hectare with 833 trees on Antonovka seedlings could be about 25 tons. In our opinion, such a crop in the seventh year is too small. On the other hand, the average crop produced by all eight cider cultivars on rootstock P 14 was $40 \mathrm{~kg}$ per tree, which gives an estimated yield of about 40 tons per ha (at 1000 trees per ha). This represents quite a good crop of processing apples in the seventh year, but the average yield is still too small to ensure a good profit. The reason is biennial bearing tendency of tested cider cultivars.

\section{CONCLUSIONS}

- Most susceptible to fire blight appeared to be following cider apple cultivars: 'Michelin', 'Yarlington Mill', 'Chisel Jersey', 'Ashton Bitter' and 'Ellis Bitter'. All of cider apple cultivars were more susceptible to fire blight than standard cultivars 'Common Antonovka', 'Wealthy' and 'James Grieve'. 
- Vigorously growing trees on Antonovka seedlings and P 14 were more sensitive to fire blight than weaker growing trees on M.26.

- Winter hardiness of one-year-old shoots of all eight cider apple cultivars was found to be very similar to that of cultivars 'James Grieve' and 'Wealthy'.

- The most vigorously growing trees on all three rootstocks were those of cultivar 'Major', while on Antonovka seedlings also those of 'Yarlington Mill' and 'Harry Master's Jersey'. Most trees of cider cultivars had similar vigor of growth to standard cultivars as 'James Grieve', 'Wealthy' and 'Common Antonovka'.

- After seven years of growing, the highest cumulative yields were obtained from trees of cultivars 'Dabinett' and 'Chisel Jersey' on all three rootstocks. Large crops were also produced by 'Michelin', 'Yarlington Mill' and 'Major'. 'Dabinett', 'Major' and 'Chisel Jersey' were highly productive and can be recommended for growing on P 14 and Antonovka seedling rootstocks in commercial orchards in Poland.

\section{REFERENCES}

CZYNCZYK A., 2001. Annual Report of testing 8 cultivars of cider apples in two experimental orchards in 2001. Res. Inst. of Pom. and Flor. Skierniewice, Poland: 1-27.

CZYNCZYK A., 2002. Annual Report of testing 8 cultivars of cider apples in two experimental orchards in 2002. Res. Inst. of Pom. and Flor. Skierniewice, Poland: 1-28.

CZYNCZYK A., 2003. Annual Report of testing 8 cultivars of cider apples in two experimental orchards in 2003. Res. Inst. of Pom. and Flor. Skierniewice, Poland: 1-24.

Fuertes M.C., DiaZ M.B., GARCIA J.C., 1996. El cultivo del manzano en Asturias. CIATA. Asturias: 1-223.

HolubowiCZ T., 1978. Survival test as a method of frost injury estimation. Acta Hort. 812: 119-122.

HÖHN E., LEUMANN R., 2004. Recommendation of fruits juice cultivars: cider type apples cultivars from cultivation to juice quality. Obst- und Weinbau 140: 4-7.

Morgan J., RichardS A., 2002. The New Book of Apples. Ebury Press Ltd., London: $1-288$.

SOBICZEWSKI P., DeCKers T., PUŁAWSKA J., 1997. Fire blight (Ervinia amylovora) some aspects of epidemiology and control (review of recent literature). Inst. of Pom. and Flor., Skierniewice, Poland: 1-85. 
VAN DER ZWET T., 1993. World spread and present distribution of fire blight an update. Acta Hort. 338: 29-31.

VAN DER ZWET T., BEER S.V., 1995. Fire blight - Its nature, prevention and control. A practical guide to integrated disease management. Agr. Inf. Bull. 631: 1-91.

VAN DER ZWET T., 1996. Present worldwide distribution of fire blight. Acta Hort. 411: 7-8.

WILLIAMS R.R., 1992. Cider and juice apples: Growing and processing. N.A.C.M. Long Ashton Research Station, Bristol, BS189AF, UK: 1-123.

\section{WZROST, OWOCOWANIE I WRAŻLIWOŚĆ NA ZARAZĘ OGNIOWA CYDROWYCH JABŁONI W WARUNKACH KLIMATYCZNYCH CENTRALNEJ POLSKI}

Streszczenie: W warunkach centralnej Polski przez 7 lat (1996 - 2003) badano możliwość uprawy 8 odmian jabłoni cydrowych szczepionych na: M.26, P 14 i siewkach Antonówki. Otrzymane wyniki wskazują, że moszczowe odmiany jabłoni są bardziej wrażliwe na porażenie przez zarazę ogniową niż standardowe odmiany: 'James Grieve', 'Wealthy' i 'Antonówka Zwykła'. Po 7 latach największe drzewa na trzech podkładkach wytworzyły odmiany: 'Ellis Bitter' i 'Major' oraz na siewkach Antonówki: 'Yarlington Mill' i 'Harry Master's Jersey'. Najmniejsze drzewa wytworzyły odmiany: 'Ashton Bitter' i 'Michelin' na trzech podkładkach. Drzewa odmian cydrowych: 'Dabinett', 'Michelin', 'Ashton Bitter' i 'Chisel Jersey' były wielkością zbliżone do drzew standardowej odmiany 'James Grieve'.

Najwyższą sumę plonów otrzymano z drzew odmian: 'Dabinett', 'Chisel Jersey' i 'Yarlington Mill' rosnących na trzech podkładkach. Wysokie plony zebrano również z drzew odmiany 'Major' szczepionych na M.26 i P 14 i odmiany 'Michelin' na P 14 i siewkach Antonówki. Odmiany 'Dabinett', 'Major' i 'Chisel Jersey' były plenne i mogą być zalecane do uprawy na P 14 i siewkach Antonówki w towarowych sadach w Polsce. 